\title{
ANALISIS BEBAN KERJA TERHADAP KARYAWAN PENYEMPROTAN TANAMAN SAWIT DI PT. EQUALINDO MAKMUR ALAM SEJAHTERA KECAMATAN TELEN KABUPATEN KUTAI TIMUR PROVINSI KALIMANTAN TIMUR
}

\section{ANALYSIS OF WORK LOAD ON THE EMPLOYEES OF OIL PLANT SPRAYING AT PT. EQUALINDO MAKMUR ALAM SEJAHTERA KECAMATAN TELEN KUTAI TIMUR REGENCY OF EAST KALIMANTAN PROVINCE}

\author{
Muhammad Prayogo Bima Pratama ${ }^{{ }^{*}}$, Elisa Herawati ${ }^{1}$, Fathiah ${ }^{1}$ \\ ${ }^{1}$ Politeknik Pertanian Negeri Samarinda \\ *bima9215@gmail.com
}

\begin{abstract}
The purpose of this study was to analyze the duties of spraying employees at work starting from the daily routine during work and then to analyze the respondents based on their respective characteristics starting from education, age, height, weight and work experience.

The method used in observing the activity and working time of spraying employees is a census by observing all of the spraying employees as many as 18 people.

The results of the calculations carried out are calculating the distribution of productive, unproductive and personal time of spraying employees for 8 hours of work so that the average productive working time of 18 samples within 8 hours of work is $85.1 \%$ and $11.5 \%$. for unproductive time and $3.4 \%$ for employee personal time. In addition, the result of the average time for completing tasks in 1 year is 136,320 minutes divided by the working time in a year that has been determined by the company, which is 114,380 minutes and multiplied by the number of respondents as many as 18 people which results in 15.10 or the same as 15 people.

The results of this study are expected to be useful for those who read or for those who want to develop existing methods into better and more effective methods and can be used as an evaluation in planning and determining the needs of spraying employees as a consideration and evaluation in the future.
\end{abstract}

Key words: Workload, Spraying and Spraying Employees

\section{PENDAHULUAN}

Pada sektor perkebunan, komoditas tanaman sawitt (Elaeis guineensis Jacq). Menempati urutan pertama sebagai penyumbang utama devisa negara Indonesia. Perkembangan produksi tanaman sawit baik Crude palm Oil (CPO) maupun palm kernel Oil (PKO), Indonesia mengalami peningkatan terusmenerus setiap tahunnya. Hal ini seiring dengan permintaan CPO dan KPO dunia yang terus bertambah banyak. Sayangnya, angka produksi tersebut di topang oleh luasan lahan perkebunan sawit (Ekspansi Lahan). Bukan karena angka produktivitas dan kualitasnya. Oleh karena itu, perlu dilakukan pembenahan tentang ruang lingkup tanaman sawit disegala sektor baik dari hulu maupun hilir (Nurhakim, 2014).

Perkebunan sawit pertama di Indonesia dirintis oleh K.schadt. Pengusaha Jerman di Tanah Itam Ulu, Sumatera Utara pada tahun 1911, juga pada tahun yang sama oleh $\mathrm{M}$. Andrien hallet, pengusaha Belgia membuka kebun sawit di Sungai Liput, Aceh Timur dan Pulau Raja, Sumatera Utara. Pada tahun 1915 luas kebun sawit $2.715 \mathrm{Ha}$, pada tahun 1939 tercatat 66 perusahaan perkebunan yang ditangani pengusaha Belanda dengan luas $\pm 100.000 \mathrm{Ha}$ dan Indonesia menjadi produsen dan eksportir minyak sawit terbesar di dunia. Pada waktu itu minyak sawit banyak dimanfaatkan sebagai minyak pelumas (Anonim, 2018). 
Produksi tanaman sawit (Crude Palm Oil dan Palm Kernel Oil) di Indonesia pada tahun 2019 menghasilkan 51.443.315 ton dengan luas areal 14.677.560 ha dan untuk provinsi Kalimantan timur memproduksi tanaman sawit (Crude palm oil dan Palm Kernel Oil) 3.164.793 ton dengan luas areal 1.107.437 ha (Anonim, 2018).

$$
\text { Kemajuan teknologi telah }
$$
mempengaruhi berbagai aktivitas termasuk aktivitas produksi barang atau jasa pada berbagai perusahaan yang bergerak di berbagai sektor, termasuk perusahaan pertanian. Hambatan pertanian yang senantiasa berubah-ubah seperti cuaca dan sumber daya alam (SDA) yang semakin terbatas seperti lahan pertanian dan bahan baku menjadikan perusahaan harus lebih kreatif, efektif dan efisien dalam menjalankan aktivitas produksinya. Sehingga untuk menghadapi hambatan tersebut dan menjaga produktivitas tetap tinggi, maka perusahaan membutuhkan sumber daya yang efektif dan efisien serta responsif terhadap perubahan. Oleh karena itu, untuk menghasilkan sumber daya yang efektif dan efisien perusahaan perlu melakukan perencanaan sumber daya manusia yang tepat sasaran untuk mendorong tercapainya visi dan misi perusahaan. Menurut Edison (2010), perencanaan Sumber Daya Manusia (SDM) adalah suatu proses yang dilakukan secara sistematis dalam rangka mempersiapkan ketersediaan sumber daya manusia yang kompeten dan berkualitas di bidangnya, serta memiliki daya saing kuat sesuai dengan arah tujuan perusahaan.

\section{METODOLOGI}

\section{Lokasi dan Waktu Penelitian}

Penelitian ini dilalukan di PT. Equalindo Makmur Alam Sejahtera yang terletak di Kecamatan Telen Kabupaten
Kutai Timur Provinsi Kalimantan Timur, Penelitian ini dilakukan dari bulan Oktober 2019 sampai dengan bulan Desember 2019.

\section{Alat dan Bahan}

Alat dan Bahan yang digunakan: Buku, kertas, pulpen, laptop, handphone dan stopwatch dan Objek: Karyawan penyemprotan dan tanaman sawit

\section{Prosedur Kerja}

1. Penentuan sampel responden

Objek penelitian adalah berupa karyawan penyemprotan tanaman sawit yang ditentukan secara sengaja (sensus) yaitu pada divisi 1 dengan jumlah keseluruhan 18 orang, karena jumlah keseluruhan dari karyawan penyemprotan adalah 18 orang, Metode yang di gunakan yaitu metode sampling jenuh atau sensus adalah teknik penentuan sampel bila semua anggota populasi digunakan sebagai sampel.(Sugiyono, 2008)

2. Mengamati aktivitas dan waktu kerja karyawan penyemprotan.

Setiap aktivitas responden terpilih di amati pada waktu jam kerja yaitu mulai dari jam 08.00 sampai dengan 16.00. Pengamatan dilakukan setiap 15 menit dan hasilnya di catat pada lembar pengamatan. Setiap responden diamati selama 7 hari. Aktifitas yang di amati adalah waktu produktif, waktu tidak produktif dan waktu pribadi.

\section{Teknik Pengolahan Data}

Produktivitas pada hakekatnya meliputi sikap yang senantiasa mempunyai pandangan bahwa metode kerja hari ini harus lebih baik dari metode kerja kemarin dan hasil yang dapat diraih esok harus lebih banyak atau lebih bermutu daripada hasil yang diraih hari ini (Komaruddin, 1992). 
1. Menetapkan waktu kerja efektif

Waktu kerja efektif adalah jumlah

hari dalam kalender dikurangi hari libur dan cuti perhitungannya kemudian hari kerja efektif di kalikan jumlah jam kerja yang diwajibkan perusahaan, rumus perhitungan hari kerja efektif adalah sebagai berikut (Anonim, 2017).

\section{Hari kerja Efektif $=(A-(B+C+D))$}

Keterangan :

$A=$ Jumlah Hari Menurut Kalender

$\mathrm{B}=$ Jumlah Hari Sabtu dan Minggu dalam

Setahunh

C = Jumlah Hari Libur dalam Setahun

$\mathrm{D}=$ Jumlah Cuti Tahunan

2. Menyusun Waktu Penyelesaian Tugas (WPT)

Waktu penyelesaian tugas merupakan hasil perkalian dari jumlah beban suatu tugas pokok dengan standar kemampuan rata-rata, waktu penyelesaian tugas tersebut dihitung berdasarkan satu kegiatan dalam satu jenis pekerjaaan yang disajikan.

3. Menghitung jumlah kebutuhan karyawan

Jumlah kebutuhan karyawan dengan demikian dapat dihitung setelah waktu penyelesaian tugas ditentukan. Rumus perhitungan jumlah kebutuhan karyawan yaitu :

Kebutuhan Karyawan $=$

$\frac{\Sigma \text { Waktu Penyelesaian Tugas }}{\Sigma \text { Waktu Kerja Efektif }} \times$ jumlah karyawan

(Muskamal, 2010)

\section{HASIL DAN PEMBAHASAN}

Hasil

Berdasarkan Informasi dari Observasi lapangan yang dilakukan oleh peneliti mengenai tugas pokok yang dikerjakan oleh Karyawan Penyemprotan adalah, sebagai berikut:

Tabel 1. Kegiatan Karyawan

Penyemprotan Tanaman Sawit

\begin{tabular}{lll}
\hline $\begin{array}{l}\text { Karyawan } \\
\text { Penyemprotan } \\
\text { Tanaman Sawit }\end{array}$ & 1 & Apel Pagi \\
& 2 & $\begin{array}{l}\text { Persiapan alat } \\
\text { kerja }\end{array}$ \\
& & $\begin{array}{l}\text { Mencari } \\
\text { Sumber Air } \\
\text { untuk mengisi } \\
\text { kep solo }\end{array}$ \\
& $\begin{array}{l}\text { Berangkat } \\
\text { menuju lokasi } \\
\text { Blok dan } \\
\text { pokok yang } \\
\text { akan } \\
\text { dilakukan } \\
\text { penyemprotan } \\
7\end{array}$ \\
& $\begin{array}{l}\text { Penyemprotan } \\
\text { Pokok }\end{array}$ \\
& $\begin{array}{l}\text { Pengisian } \\
\text { Kembali Kep } \\
\text { Pindah Lokasi } \\
\text { Kerja }\end{array}$ \\
\hline
\end{tabular}

Berbagai tugas pokok yang telah di jabarkan diatas nantinya akan digunakan untuk menganalisis beban kerja dan kebutuhan karyawan penyemprotan Divisi 1 dimana setiap karyawan penyemprotan mempunyai blok masing masing seluas 3 ha untuk dilakukan penyemprotan setiap harinya.

\section{Pembahasan}

Berdasarkan hasil pengamatan pada karyawan penyemprotan yang bekerja dengan luasan $\pm 528 \mathrm{Ha}$ di Divisi 1 bekerja selama 6 hari dalam seminggu dengan hari minggunya libur dimana mengikuti kalender bahwa hari minggu tanggal merah,

Adapun jam kerja karyawan per hari yaitu sejak pukul 06:00, dihitung dari apel pagi sampai dengan pukul 12.00 WITA dan kembali bekerja pada jam 14:00 sampai jam 16:00 dengan waktu 
kerja yang diatur oleh perusahaan dalam 1 hari 8 jam.

Hari kerja efektif dihitung dengan menghitung jumlah hari dalam setahun dikurang dengan hari minggu yang merupakan tanggal merah dan jumlah hari libur nasional dalam setahun serta dikurang jumlah cuti yang telah diatur oleh perusahaan, hasil perhitungan hari kerja efektif pada tabel 2.

Hasil perhitungan menunjukkan bahwa 1 tahun pada tahun 2019 mempunyai 365 hari dan tanggal merah hari minggu sebanyak 52 hari, libur Nasional sebanyak 13 hari serta cuti tahunan 12 hari sehingga diperoleh jumlah hari kerja efektif karyawan yaitu sebanyak 284 hari.

Karyawan Penyemprotan bekerja selama 8 jam per hari atau 480 menit, apabila satu minggu maka karyawan penyemprotan bekerja 48 jam atau 2.880 menit dengan 6 hari berkerja dan apabila 1 tahun maka $(480 \times 284=136.320)$ dapatlah nilai dari perhitungan waktu kerja efektif (WKP) dalam 1 tahun.

Dalam sebuah pekerjaan harus diukur seberapa besar waktu yang digunakan untuk penyelesaian tugasnya. Oleh karena itu, pekerjaan harus diukur dan dihitung dalam satuan waktu tertentu sehingga penyelesaian tugas dapat efektif dan efisien. Efektif terlihat dari tercapainya tujuan dalam menggunakan waktu yang telah

Efisien mengandung dua makna, yaitu makna pengurangan waktu dalam bekerja yang sudah ditentukan dan menggunakan waktu yang ada.dengan baik, Waktu penyelesaian tugas (WPT) diperoleh dengan mengalikan Beban Tugas (BT) tahunan dan Standar Kemampuan Rata-rata (SKR), yang kedua data tersebut diperoleh data sekunder berupa penghitungan kebutuhan pegawai berdasarkan beban kerja.

Tabel 2. Hasil Perhitungan Hari Kerja Efektif

\begin{tabular}{|c|c|c|c|c|c|c|}
\hline No & Bulan & Jumlah hari & Hari minggu & $\begin{array}{c}\text { Libur } \\
\text { nasional }\end{array}$ & Cuti & $\begin{array}{c}\text { Hari kerja } \\
\text { efektif }\end{array}$ \\
\hline 1 & Januari & 31 & 4 & 1 & 1 & 25 \\
\hline 2 & Febuari & 28 & 4 & 1 & 1 & 22 \\
\hline 3 & Maret & 31 & 5 & 1 & 1 & 24 \\
\hline 4 & April & 30 & 4 & 2 & 1 & 23 \\
\hline 5 & Mai & 31 & 4 & 2 & 1 & 24 \\
\hline 6 & Juni & 30 & 5 & 7 & 1 & 17 \\
\hline 7 & Juli & 31 & 4 & - & 1 & 26 \\
\hline 8 & Agustus & 31 & 4 & 1 & 1 & 25 \\
\hline 9 & Sebtember & 30 & 5 & - & 1 & 24 \\
\hline 10 & Oktober & 31 & 4 & - & 1 & 26 \\
\hline 11 & November & 30 & 4 & 1 & 1 & 24 \\
\hline 12 & Desember & 31 & 5 & 1 & 1 & 24 \\
\hline & Jumlah & 365 & 52 & 17 & 12 & 284 \\
\hline
\end{tabular}

Pengukuran Kebutuhan Karyawan
Penyemprotan Kelapa Sawit
Berikut perhitungan jumlah kebutuhan karyawan penyemprotan pada wilayah kebun Divisi satu :

Apabila pengukuran keseluruhan karyawan penyemprotan dalam satu ancak adalah 0,839 × 18 jumlah aktual karyawan penyemprotan sehingga menjadi 15 orang yang menjadi karyawan pemupukan di divisi satu.

\section{Perbandingan Jumlah Kebutuhan Karyawan terhadap Kondisi Aktual} Berdasarkan analisis diatas maka pendekatan tugas karyawan 
penyemprotan melalui perhitungan waktu penyelesaian tugas dalam 1 tahun dengan waktu efektifitas kerja dalam setahun yang di dapat dari standar kerja perusahaan di perhitungkan dalam satu tahun, hasilnya tugas yang diberikan oleh perusahaan kepada karyawan penyemprotan sangat efektif bahkan bisa dibilang efesien sekali karena perhitungan yang menunjukan 0,839 orang untuk 1 Ancak dan ancak sendiri adalah sebutan bagi wilayah penyemprotan yang akan dilakukan penyemprotan oleh 1 karyawan penyemprotan sehingga total jumlah karyawan penyemprotan menjadi 15 orang.

\section{KESIMPULAN}

Berdasarkan hasil penelitian yang telah dilakukan dengan pembahasan yang ada dengan demikian dapat di ambil kesimpulan sebagai berikut:

Dari hasil penelitian jumlah penggunaan/pemakaian waktu yang telah dibagi menjadi 3 jenis penggunaan waktu produktif, tidak produktif dan pribadi yang digunakan oleh karyawan penyemprotan dalam menyelesaikan pekerjaan penyemprotan dari 18 responden dengan 3 kali pengulangan mendapatkan rata-rata yang dikonfersikan kedalam angka persentase dengan nilai $85 \%$ produktif, $11 \%$ tidak produktif dan $4 \%$ pribadi, yang dimana persentase produktif mempunyai angka tertinggi dengan jumlah $85 \%$.

Berdasarkan pengamatan, hasil yang di dapatkan bahwa karyawan penyemprotan bekerja 8 jam dalam sehari dengan target 3 ha dengan kapasitas kep 16 liter dengan campuran air dan pestisida dengan bandingan 15 : 1 dan untuk jumlah karyawan di lapangan sebanyak 18 orang, dari perhitungan kebutuhan karyawan penyemprotan pada wilayah kebun divisi 1 seharusnya dibutuhkan sebanyak 15 orang saja.

\section{DAFTAR PUSTAKA}

Anonim, 2018. Statistik Kelapa Sawit Indonesia.

Anonim, 2018. Rencana dan Realisasi Produksi CPO. Deli Serdang.

Ardana, dkk. 2012. Manajemen Sumber Daya Manusia - Edisi Pertama. Graha IImu Yogyakarta.

Edison, Emron. Yohny anwar,Imas komariyah. (2016). Manajemen Sumber Daya Manusia. Bandung: Alfabeta.

Fakih, Mansour. 2004. Analisis Gender \& Transformasi Sosial. Yogyakarta: Pustaka Belajar.

Hasibuan, M. (2003). Organisasi dan motivasi , Jakarta : PT.Bumi Aksara.

Marwansyah. 2010. Mananajemen Sumber Daya Manusia, Alfabeta, Bandung.

Muskamal. 2010. Analisis Beban Kerja Organisasi Pemerintah Daerah. PKP2A II. LAN Makassar.

Nevia Mutia, Resisti (2016) Pengaruh Kemampuan, Pengalaman Kerja, Dan Kepuasan Kerja Terhadap Prestasi Kerja Karyawan PT. BPR Kecamatan Lengayang Kabupaten Pesisir Selatan. Sarjana thesis, STKIP PGRI SUMATERA BARAT.

Nurhakim. Y. I. 2014. Perkebunan Kelapa Sawit Cepat Panen Investasi Perkebunan paling Menjanjikan dan Menguntungkan. Infra Group, Jakarta.

Sugiyono. 2008. MetodePenelitian Kuantitatif Kualitatif dan R\&D. Bandung : ALFABETA

Sunarko, 2009. Budidaya dan Pengolahan Kebun Kelapa Sawit Dengan Sistem Kemitraan. Jakarta. Agromedia Pustaka.

Ningrum Widhayu, DKK. 2013. Pengauh Pendidikan dan Pelatihan Terhadap Kinerja Karyawan(Studi Pada Karyawan Joint Operating Body Pertamina-PertoChina East Java).UniversitasBrawijayaJurnal Administrasi Bisnis (JAB)| Vol. 6 No. 2

Zahrotul Munawwaroh, 2017 ANALISIS MANAJEMEN RISIKO DALAM 
MENINGKATKAN MUTU

PENDIDIKAN DASAR DI

SD/PRIMARY MADANIA TELAGA

KAHURIPAN BOGOR DAN MI

PEMBANGUNAN UIN JAKARTA

Universitas Pendidikan Indonesia. 